\title{
拡散噴流強制火花点火による水素の急速燃焼抑制*
}

\author{
木戸口 善行*1, 池 田 大 志*2, 嘉 本 耕 治*3 \\ Ali MOHAMMADI*4, 三 輪 惠*1
}

\section{Control of Rapid Combustion of Hydrogen Jet Ignited by Spark Plug}

\author{
Yoshiyuki KIDOGUCHI ${ }^{* 5}$, Daishi IKEDA, Koji KAMOTO, \\ Ali MOHAMMADI and Kei MIWA \\ ${ }^{* 5}$ Department of Ecosystem Engineering, The University of Tokushima, \\ 2-1 Minamijosanjima, Tokushima-shi, Tokushima, 770-8506 Japan
}

\begin{abstract}
This study tried to control rapid combustion of hydrogen fuel. Experiment was carried out using constant volume chamber. Hydrogen was injected in this chamber using gas injector and the jet was ignited by a spark plug. High-speed schlieren photography method using high-speed digital video camera was employed to observe combustion process of hydrogen jet. Combustion process was analyzed by the photographs and pressure history. It has been shown by the results that igniting hydrogen spray can control rapid combustion. The spark plug should be located in the boundary of the spray near the outlet of injector in order to reduce initial pressure rise of hydrogen combustion. This kind of injector location also improves combustion efficiency, because combustion continues mainly in the internal of the chamber leading to the reduction of quenching on the wall. Early ignition during injection further reduces initial rapid pressure rise of hydrogen jet.
\end{abstract}

Key Words: Gaseous Fuel, Combustion, Flame, Hydrogen, Jet, Spark Ignition

\section{1. まえがき}

水素および天然ガスは，資源枯渇と大気污染問題の 観点から次世代の内燃機関用燃料として注目され，カ 不機関の研究開発が進められている(1)-(4). とくに, 水 素はリサイクル性をもち， $\mathrm{CO}_{2}$ や $\mathrm{HC}$ を排出しないこと から将来燃料として有望である. また，可燃範囲が広 く最小点火エネルギーが低いことから, 希薄然焼が実 現できて Nox 低減に有利であり, 低負荷では燃焼変動 を小さくすることができる. しかし, 逆火, 過早着火, ノッキングなどの異常燃焼が起こる包。これら, 水 素が急速燃焼を起こすことに起因しており, 熱損失も 大きくなって熱効率も低くなる. このため, 水素では 急速然焼を抑制することが課題になっている.

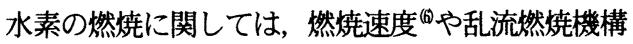
ゆゅ，化学反応機構 ${ }^{(9)}$ などの基本的事項が調べられて いるが，急速燃焼については，実機関を用いて高速回 転による急速澎張で異常燃焼を抑制すること们などが 行われているものの, 急速燃焼を抑制する方法は確立

* 原稿受付 2003 年 12 月 5 日

${ }^{* 1}$ 正員, 徳島大学大学院工学研究科( $770-8506$ 徳島市南常 三島町 2-1).

*2 マツダ(株).

$* 3$ 三菱農機 (株)

${ }^{* 4}$ 正員, 京都大学大学院エネルギー科学研究科.

E-mail : kidog@eco.tokushima-u.ac.jp
していない.

そこで本研究では, 水素の急速㜣焼を抑制するため に，拡散噴流に火花点火させることを検討した．この 場合，燃焼は燃料と空気の混合に支配される㹡散㜣焼 になる. すなわち，抬散噴流において，燃料噴射初期 に形成された可燃範囲にある混合気を火花点火により 着火させ, 後続の噴射された燃料を順次燃焼させるこ とにより急速燃焼を抑制する. 実験でははじめに, 高 速シュリーレン法と画像処理および然焼圧力解析によ り, 定容容器内の水素噴流の火炎構造および燃嬅過程 を天然ガス噴流と比較して, 水素の燃焼機構を調べ, つぎに点火条件を変更することにより，拡散噴流燃泋 において最適な水素の急速燃焼抑制方法について検討 した.

\section{2. 実的および方法}

本研究では, 高速シュリーレン法によってガス噴 流燃焼における火炎発達過程を解析した. 図 1 に実験 装置の概略を示す．シュリーレン撮影装置は光源，凹 面鏡，シュリーレンストップ（直径 $2.0 \mathrm{~mm}$ ) から構成 されている. 光源にはキセノンランプ (ウシオ電機 UXI-1000D-0, 出力 $1 \mathrm{~kW}$ ) を用い, 凹面鏡は, 鏡径 $200 \mathrm{~mm}$, 焦点距離 $2000 \mathrm{~mm}$ とした. 撮影には高速度デジタルビ デオカメラ(Eastman Kodak Ektapro HS4540)を使用し, 


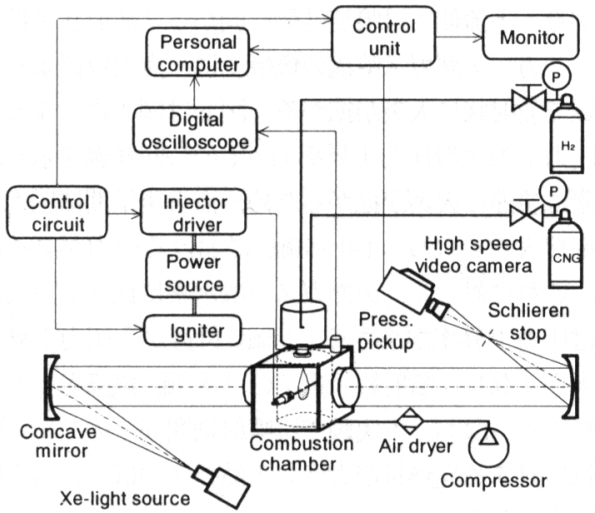

Fig.1 Schematic diagram of experimental apparatus

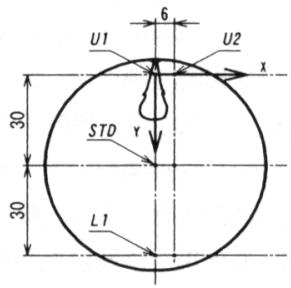

Fig.2 Spark position

撮影速度は 9000pps とした. 燃焼容器は, 内径 90mm, 容積 $613 \mathrm{cc}$ の円筒形定容容器で, 光軸が通過する 2 面 に直径 70m の観察空を, 直交する 2 面には点火プラ グを設けた. 点火プラグの電極には直径 $1.2 \mathrm{~mm}$ の $\mathrm{Ni}$ 棒を使用し, 電極間距離を $0.8 \mathrm{~mm}$ とした. 燃料の水素 および天然ガスは, 燃料噴射圧力を一定に保つために 燃焼室上部に設けた蓄圧室を介して，筒内直接噴射用 ガス噴射弁を用いて噴射した。

実験では，噴射期間 $10 \mathrm{~ms}$ 一定で雾囲気圧力 $\mathrm{p}_{\mathrm{a}}$ を 0.5 〜 $1.0 \mathrm{MPa}$ ，噴射圧力 $\mathrm{p}_{\mathrm{j}}$ を $1.0 \sim 3.0 \mathrm{OPa}$ まで変化させる とともに点火位置および点火時期を変更して燃焼観察 および圧力測定を行った. 当量比は, 噴射圧力 $\mathrm{p}_{\mathrm{j}}=3.0 \mathrm{MPa}$, 䨌囲気圧力 $\mathrm{p}_{\mathrm{a}}=0.5 \mathrm{MPa}$ のときに 0.06 , $\mathrm{p}_{\mathrm{j}}=1.0 \mathrm{MPa}, \mathrm{p}_{\mathrm{a}}=0.75 \mathrm{MPa}$ のときに 0.02 であった. 点火位 置 $S_{p}$ は, 図 2 に示す中心点火位置を STD とし, 噴射軸 上で STD に対して $30 \mathrm{~mm}$ 下流側の位置 $\mathrm{L} 1,30 \mathrm{~mm}$ 上流側 で噴孔から5mm 離れた位置 U1，および $\mathrm{U} 1$ に対して噴 射軸垂直方向に 6 mm 離れた噴流境界位置 U2 に変化さ せた. いずれの場合も, 電極は対向させて設置してい る. 標準点火時期 $\mathrm{t}_{\mathrm{ig}}$ は噴流が点火位置に達した時に 点火することとし, 噴射開始後 0 〜 10ms までの間で点 火時期を変化させた. 噴射開始からの時間および点火 してからの時間をそれぞれ $t_{10}$ および $\mathrm{t}$ とすると, $\mathrm{t}_{\mathrm{i}} \mathrm{t} \mathrm{t}_{0}-\mathrm{t}$ で表される. 燃焼圧力は圧電式圧力変換器(AVL GI21D)を使用して測定し, 各実験条件では, 5 回以上

繰り返して実験を行い，燃燒圧力経過の一致をもって 燃焼の再現性を確認した.

噴流拡散燃焼では周囲空気が噴流にエントレインさ れて，噴流内で燃料と空気の混合過程と燃焼反応が同 時進行する．燃焼は噴流内の至るところで起こり，火 炎が乱れによって凹凸を生じ，シュリーレン画像では 多数の輝度むらが観察される.このような輝度むらを トレーサとして, 画像相互相関法 ${ }^{(1)}$ を適用して火炎画 像を解析し，燃燒過程を調べた。

\section{3. 実器拮果}

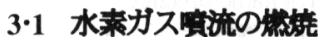

$3 \cdot 1 \cdot 1$ 天然ガスとの比水素ガスの噴流燃焼 の特徴を明らかにするために，天然ガス噴流の燃焼と の比較を行った. はじめに, 噴流到達距離を調べた. 図 3 は雲囲気圧力 $\mathrm{p}_{\mathrm{a}}=0.5 \mathrm{MPa}$ として, 噴射圧力を $\mathrm{p}_{\mathrm{j}}=1.0$ 〜5. OMPa に変化させたときの水素および天然ガス噴流 の噴流到達距離 $\mathrm{L}$ を噴射してからの時間 $\mathrm{t}_{0}$ に対して示 す。いずれの噴射圧力でも水素と天然ガスはほぼ同等 の噴流到達距離を示すことがわかる.

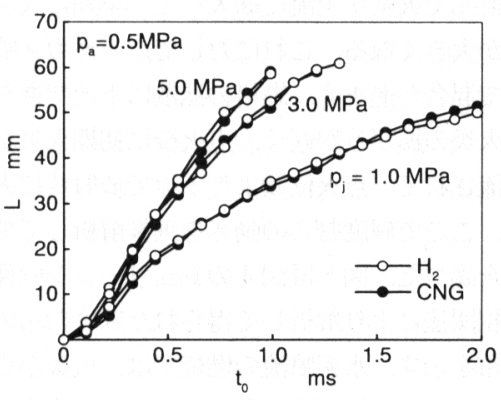

Fig.3 Comparison of tip penetration between $\mathrm{H}_{2}$ and $\mathrm{CNG}$ jet

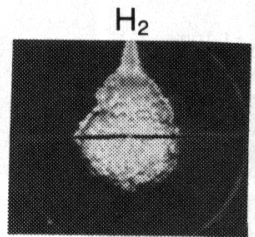

$\mathrm{t}=1.21 \mathrm{~ms}$

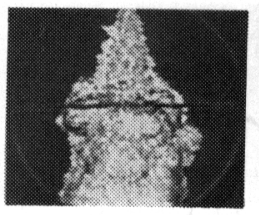

$\mathrm{t}=5.06 \mathrm{~ms}$

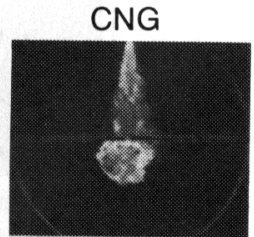

$1.21 \mathrm{~ms}$

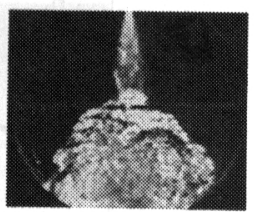

$6.93 \mathrm{~ms}$ $\mathrm{p}_{\mathrm{i}}=1.0 \mathrm{MPa}, \mathrm{p}_{\mathrm{a}}=0.75 \mathrm{MPa}, \mathrm{S}_{\mathrm{p}}=\mathrm{STD}$

Fig.4 Comparison of flame development 

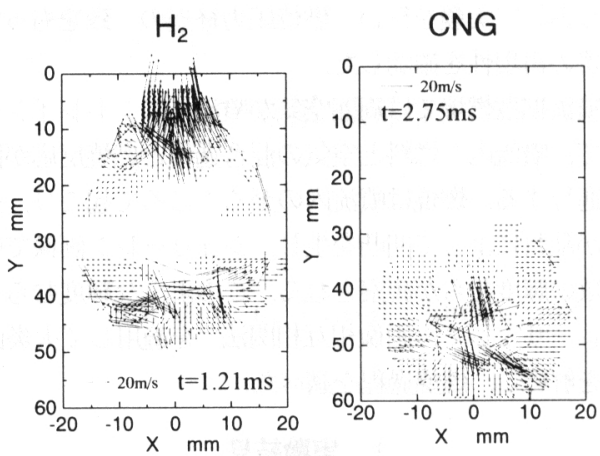

Fig.5 Comparison of flame structure between $\mathrm{H}_{2}$ and $\mathrm{CNG}$ jet

つぎに, $p_{a}=0.75 \mathrm{MPa}, p_{\mathrm{j}}=1.0 \mathrm{MPa}$ のもとで，水素およ び天然ガス噴流を中心点火（ $\mathrm{S}_{\mathrm{p}}=\mathrm{STD}$ ) で燃焼させた. 図 4 にこのときの火炎発達過程をシュリーレン撮影し た結果を示す．時間 $\mathrm{t}$ は点火してからの経過時間であ る. 水素噴流の燃焼経過をみると, 点火直後から電極 を中心として火炎全体が放射状に揓がる. また，大き な拡散速度をもつ水素では，噴流上流でも空気との混 合が進んで火炎が上流に拡大して，早期に火炎の投影 面積が大きくなる.これに対して，天然ガス噴流では 上流で混合が進まず，燃料の挔散は下流で進む。この ため火炎の拡がりが遅く, 点火後に初期火炎が噴流に 押し流されて，点火位置より下流で放射状に火炎が拡 がる.ここで輝度むらの動きを画像解析して挔散燃焼 経過を調べた。図 5 は図 4 のシュリーレン画像を画像 相互相関法により解析して得られた輝度むらの瞬間速 度分布を示す．水素噴流の燃焼では，火炎が点火位置 (Y=30mm) より上流側で噴流に対して逆流するように

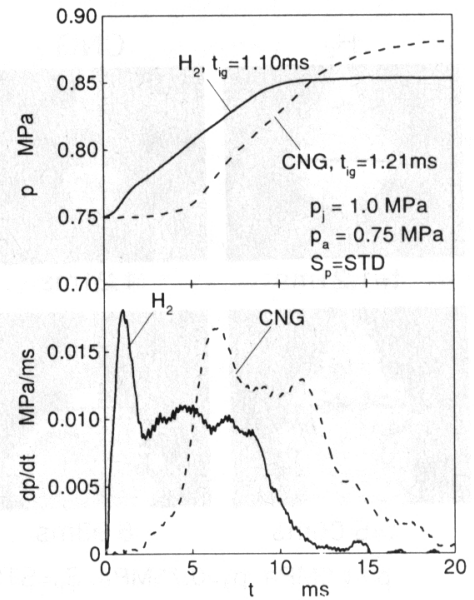

Fig.6 Comparison of combustion pressure
挔がり，下流側では噴流外側に向かって放射状に拡が る. 一方, 天然ガス噴流の燃焼では，点火位置より下 流域で放射状に火炎が拡がる. 図 6 は図 4 に対する燃 焼圧力 $\mathrm{p}$ および圧力上昇率 $\mathrm{dp} / \mathrm{dt}$ の時間経過を示す. 水素は急速に火炎が搪がるため, 点火後早期に圧力上 昇率が大きくなり， $t=0$ ～10ms における圧力が高くな る.これに対して，天然ガスでは水素に比べて点火直 後は圧力上昇率が小さく, $\mathrm{t}=5 \mathrm{~ms}$ 付近から圧力上昇率 が大きくなり，噴射終了近くの $\mathrm{t}=8.7 \mathrm{~ms}$ 以降も圧力が 上昇する．なお，本実験では噴射期間同一のため，噴 射量に対する発熱量が大きい天然ガスのほうが最大圧 力が高くなる.

$3 \cdot 1 \cdot 2$ 㝜射圧力およひ突囲気圧力の影留 つぎ に，噴射圧力 $p_{j}$ および雾囲気圧力 $p_{a}$ が水素噴流の火 炎発達過程に及ぼす影響を調べた。図 7 にSTD 点火で $\mathrm{p}_{\mathrm{j}}$ および $\mathrm{p}_{\mathrm{a}}$ を変化させたときの燃焼圧力 $\mathrm{p}$ の経過, 図 8 に火炎のシュリーレン画像を示す．噴射圧力を高く すると，圧力上昇率が大きくなり，噴流下流方向だけ でなく上流方向へも火炎が早期に抾がる. また，噴射 圧力が高いほど輝度むらが細かくなる，一方，雲囲気 圧力が高くなると，燃焼圧力は高いが火炎全体の拡が りが遅くなる.このような燃焼過程を定量化するため に，シュリーレン画像における輝度むらの大きさと瞬 間速度分布を解析した. 図 9 は画像から得られた輝度

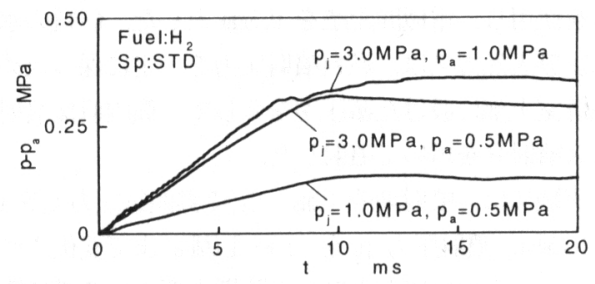

Fig.7 Comparison of combustion pressure

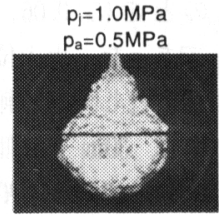

$\mathrm{t}=1.65 \mathrm{~ms}$

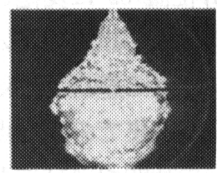

$\mathrm{t}=2.31 \mathrm{~ms}$

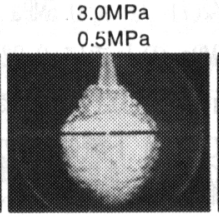

0.66

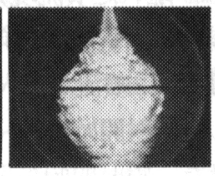

0.88

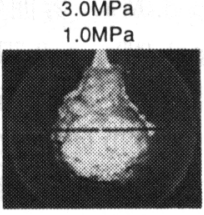

0.99

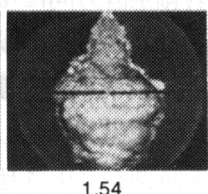

Fuel: $\mathrm{H}_{2}, \mathrm{Sp}=\mathrm{STD}$
Fig.8 Effect of injection pressure and ambient pressure on flame development of $\mathrm{H}_{2}$ jet 

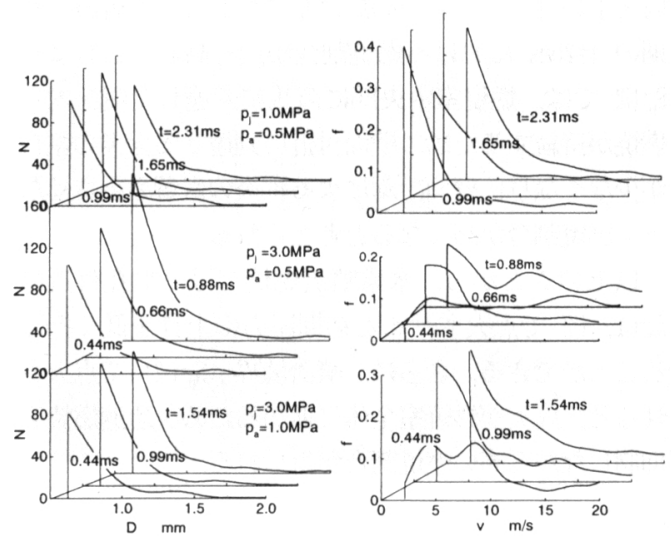

Fig.9 Flame cell size and flame speed

むらを真円と仮定したときの直径 D とその個数 N，お よひ瞬時速度 v の頻度 $\mathrm{f}$ の分布について, 火炎発達過 程の各時間で示したものである. 䨌囲気圧力の低い $\mathrm{p}_{\mathrm{a}}=0.5 \mathrm{MPa}$ の $\mathrm{p}_{\mathrm{j}}=1.0 \mathrm{MPa}$ と $3.0 \mathrm{MPa}$ の比較から, 噴射圧力 が低いと輝度むらの移動速度は $\mathrm{v}=5 \mathrm{~m} / \mathrm{s}$ 以下の割合が 多く, 時間に対して輝度むらの大きさはあまり変わら ない，これに対して，噴射圧力が高いと輝度むらは $\mathrm{v}=10 \mathrm{~m} / \mathrm{s}$ 以上の高い移動速度を維持して, $\mathrm{D}=0.6 \mathrm{~nm}$ 以下 の細かい輝度むらが時間とともに増加する．噴射圧力 $\mathrm{p}_{\mathrm{j}}=3 . \mathrm{OMPa}$ として雾囲気圧力を $\mathrm{p}_{\mathrm{a}}=1.0 \mathrm{MPa}$ に高くすると, $\mathrm{p}=0.5 \mathrm{MPa}$ に比べて $\mathrm{t}=0.99 \mathrm{~ms}$ 以降で輝度むらの移動速度 が小さくなり, $\mathrm{D}=0.6 \mathrm{~mm}$ 以下の細かい輝度むらの増加 が抑元られる。

以上をまとめると, 水素噴流では天然ガスに比べて
拡散燃焼における火炎の拡がりが速く, 点火位置を中 心にして放射状に火炎が搪がる.これにともない点火 直後の圧力上昇率が大きくなる．また，噴射圧力が高 くなると，噴流内部での混合が進んで燃焼が活発にな るため，火炎画像にあらわれる輝度むらが細かくなる.

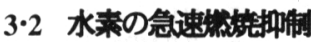

$3 \cdot 2 \cdot 1$ 点火位圈の効果 ここでは, 水素噴流の 着火之燃焼に大きな影響を及ぼす点火条件について検 討した. はじめに, 雰囲気圧力 $\mathrm{p}_{\mathrm{a}}=0.5 \mathrm{MPa}$ ，噴射圧力 $\mathrm{p}_{\mathrm{j}}=3.0 \mathrm{MPa}$ の条件で点火位置 $\mathrm{S}_{\mathrm{p}}$ を図 2 に示す STD, U1, U2 およびL1の 4 力所に変更した. 図 10 はこのときの シュリーレン画像を示す. 図中の時刻 $\mathrm{t}_{0}$ は, 水素を 噴射してからの時間, $\mathrm{t}$ は点火後の経過時間を示す. 中心点火（Sp=STD）の場合は，火炎が点火位置を中心 に放射状に拡がるのに対し，噴孔近くの $\mathrm{S}_{\mathrm{p}}=\mathrm{U1}$, U2 で 点火すると, 火炎は上流の点火位置から筒状に抎がり, 噴流全体で燃焼しながら噴流火炎が発達する. とくに 噴射軸に対して離れた噴流境界位置で点火させた $\mathrm{S}_{\mathrm{p}}=\mathrm{U2}$ では, $\mathrm{S}_{\mathrm{p}}=U 1$ に比べると噴流下流方向への火炎の 拡がりは遅いが，噴流内部での燃焼が盛んとなり，太 い筒状の火炎を形成して燃焼室全体に火炎が搪がる. これは， $\mathrm{S}_{0}=U 2$ では噴孔付近で噴流が電極に衝突して 速度が低下するため, 初期火炎の形成が安定化するこ とと, さらに, 点火位置が噴流境界のため燃料と空気 との混合が促進され，初期火炎が噴流内に取込まれて 火炎の抎がりが大きくなったためと考えられる。噴孔 から離れた壁面に近い位置（S=L1）で点火すると, 壁 面近くで着火して火炎が下流から上流に発達する。

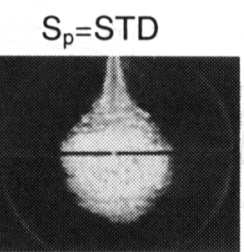

$\mathrm{t}=0.44 \mathrm{~ms}$ $\mathrm{t}_{0}=0.88 \mathrm{~ms}$

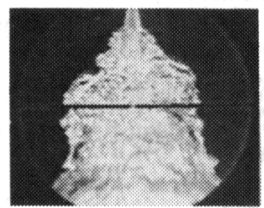

$\mathrm{t}=1.87 \mathrm{~ms}$ $\mathrm{t}_{0}=2.31 \mathrm{~ms}$
U1

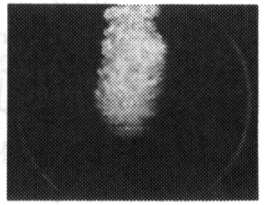

$0.44 \mathrm{~ms}$

$0.55 \mathrm{~ms}$

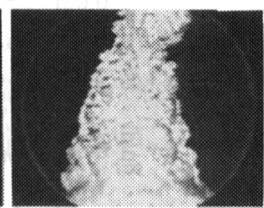

$1.87 \mathrm{~ms}$

$1.98 \mathrm{~ms}$
$\mathrm{H}_{2}, \mathrm{p}_{\mathrm{i}}=3.0 \mathrm{MPa}, \mathrm{p}_{\mathrm{a}}=0.5 \mathrm{MPa}$

$\mathrm{U} 2$

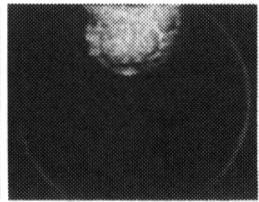

$0.44 \mathrm{~ms}$

$0.66 \mathrm{~ms}$

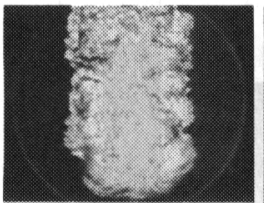

$1.87 \mathrm{~ms}$

$2.09 \mathrm{~ms}$
L1

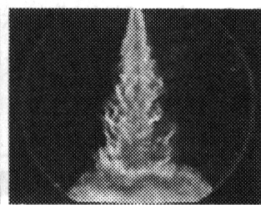

$0.44 \mathrm{~ms}$

$1.65 \mathrm{~ms}$

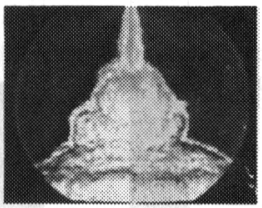

$1.87 \mathrm{~ms}$

$3.08 \mathrm{~ms}$

Fig.10 Effect of ignition position on flame development of $\mathrm{H}_{2}$ jet 


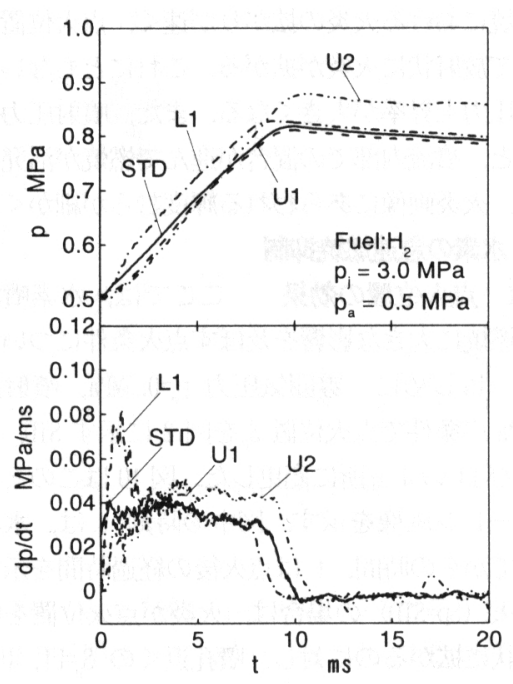

Fig.11 Effect of ignition position on history of combustion pressure

図 11 は点火位置を変更したときの燃嬅圧力 $\mathrm{p}$ と圧 力上昇率 $\mathrm{dp} / \mathrm{dt}$ の経過を示す. 噴孔付近点火である $\mathrm{S}_{\mathrm{p}}=\mathrm{U1}$, U2 にすると, 点火までに噴射される燃料量が 少ないため $\mathrm{S}_{\mathrm{p}}=\mathrm{STD}$ に比べて $\mathrm{t}=0$ \% $5 \mathrm{~ms}$ の燃焼初期にお ける圧力上昇率を低く抑えることができる. また, $\mathrm{t}=5 \mathrm{~ms}$ 以降では, U1 は STD と同様の圧力経過をたどる が, U2 では圧力上昇が大きく, 最大圧力が最も高く なる. 燃焼室底面付近の $\mathrm{S}_{\mathrm{p}}=\mathrm{L} 1$ では, 点火位置が噴孔 から遠く, 点火までに多くの燃料が噴射されて燃焼す るため, 他の点火位置に比べて $\mathrm{t}=8 \mathrm{~ms}$ までは初期燃焼 圧力が高くなる.

図 12 は, 各点火位置で燃焼圧力から燃焼による発 熱量を算出して総噴射量に対する燃焼割合 $Q_{\mathrm{p}} / Q_{1}$ を求 め, 点火開始から $5 \mathrm{~ms}$ 毎に積上げ表示したものである. 噴流境界点火の $\mathrm{S}_{\mathrm{p}}=\mathrm{U2}$ では, 他の点火位置に比べて噴

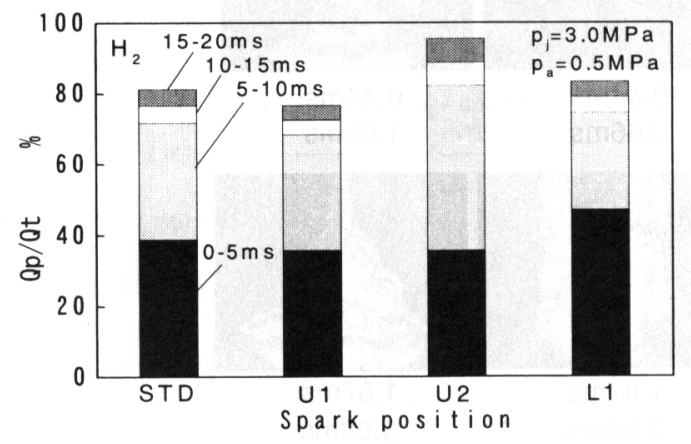

Fig.12 Effect of spark position on history of accumulated heat release
射後半の $\mathrm{t}=5 \sim 10 \mathrm{~ms}$ での燃焼割合が高く, 燃焼終了時 期の $\mathrm{t}=20 \mathrm{~ms}$ における燃焼割合が最も高い。これより, $\mathrm{S}_{\mathrm{p}}=\mathrm{U} 2$ では, 燃焼室中央部に筒状に発達した噴流内で 燃焼が持続するため, 壁面付近に到達する火炎の割合 が少なくなり，壁面冷却による消炎の影響も小さくな つて燃焼割合が高くなると考えられる.

以上のことから, 水素噴流燃焼では, 噴孔付近の $\mathrm{S}_{\mathrm{p}}=\mathrm{U1}$, U2 で点火させると初期圧力の上昇を低く抑え ることができる，さらに，噴流境界（ $\mathrm{S}_{\mathrm{p}}=U 2 ）$ で点火さ せると，火炎が燃焼室全体に拡がるため，急速燃焼を 抑制しながら高い燃焼割合が得られる。

$3 \cdot 2 \cdot 2$ 点火時期の効果 つぎに, 点火時期による 水素の急速燃焼抑制について調べた. 図 13 は水素の 初期燃焼圧力上昇を抑えることができる点火位置 $S_{p}=U 2$ のもとで, 雾囲気圧力 $p_{a}=0.75 \mathrm{MPa}$, 噴射圧力 $\mathrm{p}_{\mathrm{j}}=1.0 \mathrm{MPa}$ の条件で, 点火時期 $\mathrm{t}_{\mathrm{ig}}$ を噴射直後 $\mathrm{t}_{\mathrm{ig}}=0 \mathrm{~ms}$ か ら噴射終了時 $\mathrm{t}_{\mathrm{ig}}=10 \mathrm{~ms}$ まで変化させたときの燃焼圧力 と圧力上昇率の経過を噴射開始からの時間 $\mathrm{t}_{0}$ に対し て示す. 図より, $S_{p}=U 2$ で点火時期を早くすると, 燃 焼初期における圧力上昇率がさらに低くなり, 点火か ら最大圧力に達するまでに要する期間が長くなって急 速燃焼が抑えられる. とくに $\mathrm{t}_{\mathrm{i}=}=0 \mathrm{~ms}$ の場合には, 圧 力 $\mathrm{p}$ が緩やかな公配を維持して上昇する期間が噴射終 了まで続く.これは, 噴射直後に点火した場合, 燃料 を噴射しながら燃焼が持続する噴流燃焼形態となるた めである. $\mathrm{t}_{\mathrm{i}}=2.5 \mathrm{~ms}$ の場合は, 点火直後から $\mathrm{t}_{0}=4 \mathrm{~ms}$ 付 近にかけては, 点火時期までに噴射された燃料が燃焼

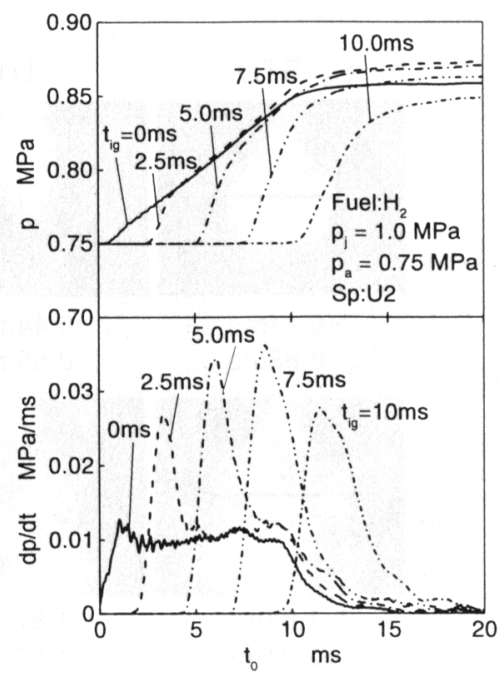

Fig.13 Effect of ignition timing on history of combustion pressure 


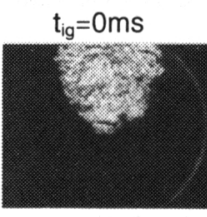

$\mathrm{t}=1.98 \mathrm{~ms}$ $\mathrm{t}_{0}=2.64 \mathrm{~ms}$

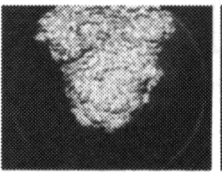

$\mathrm{t}=4.18 \mathrm{~ms}$ $\mathrm{t}_{0}=4.84 \mathrm{~ms}$

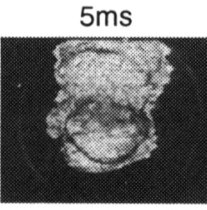

$1.98 \mathrm{~ms}$ $7.04 \mathrm{~ms}$

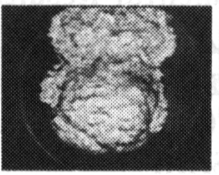

$4.18 \mathrm{~ms}$

$9.24 \mathrm{~ms}$

Fuel: $\mathrm{H}_{2}, \mathrm{p}_{\mathrm{i}}=1.0 \mathrm{MPa}, \mathrm{p}_{\mathrm{a}}=0.75 \mathrm{MPa}, \mathrm{S}_{\mathrm{p}}=\mathrm{U} 2$

Fig.14 Effect of ignition timing on flame development

するため点火直後の圧力勾配が大きくなるが， $\mathrm{t}_{0}=4 \mathrm{~ms}$ 以降は噴射された燃料が順次燃焼する形態となるため, $\mathrm{t}_{\mathrm{i} g}=0 \mathrm{~ms}$ の場合と同様に緩やかな圧力公配になる. 点火 時期を $\mathrm{t}_{\mathrm{ig}}=5 \mathrm{~ms}$ 以降に遅らせると, 点火までに燃焼室 内に噴射される燃料の量が多くなり，予混合燃焼の形 態に近い急激な燃焼となるため，圧力の立上がりが大 きくなる. 噴射終了時点火の $\mathrm{t}_{\mathrm{ig}}=10 \mathrm{~ms}$ では, 点火時期 が遅いため燃料が拡散し，可燃濃度範囲以下の領域が 増加するため圧力上昇率および最大圧力が低くなる。

図 14 は点火時期を変化させたときの燃焼経過のシ ユリーレン画像である. $\mathrm{t}_{\mathrm{i} \mathrm{k}}=0 \mathrm{~ms}$ では噴流下流への火炎 の搪がりが少なく, 点火後に噴射された燃料が燃狫室 中央付近で然焼する. $\mathrm{t}_{\mathrm{ig}}=5 \mathrm{~ms}$ および $7.5 \mathrm{~ms}$ では点火直 後の火炎の搪がりは $\mathrm{t}_{\mathrm{i}}=0 \mathrm{~ms}$ の場合より大きく, その 後圧力上昇率の低下とともに火炎の拡がりは緩やかに なり，後続の噴射された燃料は上流から中央付近で然 焼する.

以上より, 水素噴流燃焼で初期燃焼における圧力上 昇率を抑えるためには，点火時期を早くして燃料噴射 初期に点火し，噴射率律速による燃焼制御をすること が有効である.

\section{4. まとめ}

水素噴流の着火・燃焼過程をシュリーレン法によ る火炎観察と燃焼圧力解析により調べて, 天然ガス噴 流との燃焼形態の相違を明らかにした，さらに，拡散
噴流火花点火による水素噴流の着火およひ燃焼制御方 法を検討した. おもな結果をまとめると次の通りにな る.

（1）水素は天然ガスに比べて混合がさかんで, 点火位 置を中心にして火炎全体が放射状に抎がり，噴流 上流へも火炎が拡がる. これにともない点火後に 燃焼圧力が急速に上昇する.

（2）水素噴流燃焼では，噴孔付近で点火させると，燃 焼初期の圧力上昇率が低くなり水素の急速燃焼を 抑えることができる.

（3）さらに，噴孔付近で噴射軸から離れた噴流境界位 置で点火すると, 噴流が電極に衝突して噴流速度 が低下する効果も加わって着火が安定化し, 火炎 が燃焼室全体に拡がって高い燃焼割合が確保でき る.

（4）水素噴流燃焼で急速燃焼を抑制するためには，点 火時期を早くして噴射率律速による燃焼制御が有 効である.

終わりに, 本研究を進めるにあたり, 実験にご便宜 を賜ったトヨ夕自動車侏殿に厚く御礼申し上げます.

\section{文 献}

(1) M. Ikegami, K. Miwa and M. Shioji, Int. J. Hydrogen Energy, Vol.7, No.4, pp.341-353, 1982.

（2）小林春樹, 松下智彦, 古浜庄一, 機論 (B編)， 55 巻 511 号, pp.895-903, 1989.

(3) K. Kato, K. Igarashi, M. Masuda, K. Otsubo, A. Yasuda, K. Takeda and T. Sato, SAE 1999-01-0574.

(4) 石山拓二, 塩路昌宏, 田中大樹, 中川秀樹, 中井俊 作，自技論，Vol.34，N0.3，pp.29-34，2003.

(5) 近藤卓, 飯尾秀一, 昼間勝, 古濱庄一, 機論 ( B 編），63巻 610号, pp.2209-2214, 1997.

(6) G. W. Koroll, R. K. Kumar and E. M. Bowles, Combust. Flame, Vol.94, pp.330-340, 1993.

(7) K. Koyanagi, M. Hiruma, K. Yamane and S. Furuhama, SAE 931811,1993.

(8) 城戸裕之, 中原真也, 機論（B編）, 63 巻 614 号, pp3477-3482, 1997.

(9) 南雲義郎, Catherina Dewi Wijaya, 伏見千尋, 越光男, 火薬学会誌, Vol.63, No.2, pp.65-72, 2002.

(10) Masahiro Shioji, Yusuke Houki and Takuji Ishiyama, Proc. Of the $13^{\text {th }}$ World Hydrogen Energy Conference, pp.641-647, 2000.

(11) 塩路昌宏, 紀本孝, 岡本昌章, 池上詢, 機論 (B 編）， 54 巻 504号, pp.2228-2233， 1988. 